\title{
Balancing Environmental Protection and Energy Production in the Federal Hydropower Licensing Process
}

\section{Lea Kosnik}

\begin{abstract}
The U.S. Federal Energy Regulatory Commission (FERC) must balance environmental protection of riverine resources with the nation's growing demand for power production every time it issues a hydroelectric license. This paper models the bureaucratic agency's decision-making process in issuing these licenses. Data on nearly 500 hydropower licenses issued from 1983 to 2005 are utilized. It is discovered that legislative and institutional constraints are, by far, the largest influences on FERC's regulatory decisions, implying that if the current allocation of surface water in the United States is considered inefficient, the most effective way to alter this allocation is by passing new legislation, or by implementing institutional reform at FERC. (JEL Q25, Q42)
\end{abstract}

\section{INTRODUCTION}

Energy needs and environmental concerns are two of the most pressing issues facing the world today. Frequently, they come into conflict. We can increase domestic oil production, but at the cost of drilling in an arctic wildlife refuge. We can burn more abundant coal stocks, but at the cost of rising air pollution. And we can dam more rivers and generate more hydroelectric power, but only at the cost of interrupting natural river flow and harming aquatic resources. How are such important trade-offs to be made? The objective of this research is to model and analyze how such trade-off choices between energy generation and environmental concerns are actually being made, in particular, in the context of hydroelectric power generation.

Land Economics - August 2010 • 86 (3): $444-466$ ISSN 0023-7639; E-ISSN 1543-8325

(C) 2010 by the Board of Regents of the

University of Wisconsin System
Hydroelectric power, or electricity generated by large turbines located at the bottom of reservoirs created from large dams, has been a viable technology since the late nineteenth century (Edwards 2003). At that time, when the industrial revolution was at its height and economic development of the nation was at center stage, the federal government's official mandate was to encourage hydroelectric production in the United States. Competing demands for the services of the nation's rivers toward more environmental ends did not begin to make inroads into official legislative expression until the late 1960 s and early 1970 s, after passage of legislation such as the National Environmental Policy Act (1969), the Clean Water Act (1972), and the Endangered Species Act (1973). Today, the Federal Energy Regulatory Commission (FERC), the agency in charge of hydropower regulation, has a clear mandate to balance both power interests and environmental concerns. Over the past 25 years, FERC has been struggling to interpret just how, in practice, to balance these competing interests over one of the nation's most important resources: its rivers.

FERC is able to affect this environmental protection/hydropower production tradeoff when it issues licenses for hydropower dams. All nonfederal hydropower dams in the United States must be licensed every 30 to 50 years in order to legally operate. This

The author is associate professor, Department of Economics, University of Missouri-St. Louis. The author gratefully acknowledges the insightful comments and help provided by John Whitehead, John Tschirhart, Lynne Lewis, Trudy Ann Cameron, J. R. DeShazo, and numerous conference participants. This research was also generously funded by the University of Missouri-St. Louis internal grants program. 
licensing process is the only official opportunity during the lifetime of a dam for a complete review of its safety and operations. It is also the only opportunity for mandated revisions of its inherent energy/ environmental operational trade-offs. For example, FERC could require dam owners to limit the flow of water through the dam's turbines. This would reduce electricity production, but it would also help eliminate irregular rushes of water that cause stream bank erosion and damage to aquatic nesting sites. Other methods FERC could impose to help the riverine environment (such as fish ladders, modified turbines, etc.) similarly tend to negatively affect electricity production. More environmental protection implies less hydroelectricity production. In the end, when FERC issues a license mandating a certain level of environmental protection, it is implicitly choosing a certain trade-off between environmental protection and hydropower production. What influences FERC's choice?

The significant influences on regulatory agency decision making are still debated in the literature. Four popular theories of regulatory influence include regulatory capture theory, congressional dominance theory, discretionary theory, and theories of institutional/historical constraints. I included variables on all four of these categories of influence in the regression analyses to determine which, if any, have affected FERC's environmental regulatory decisions when issuing hydropower licenses. The data spans 1983-2005 and includes the approximately 500 hydropower licenses that were issued over this period.

The findings are that, while there is support for all four categories of influence in affecting FERC's behavior, by far the largest influences on FERC's regulatory decisions are Congress and institutional history. Legislation passed by Congress and put into effect in 1990, for example, increased the level of environmental protection mandated by $19 \%$. Similarly, Senate oversight can affect the hydropower production/environmental protection balance by as much as $17 \%$. Historically, we find that relicensing decisions are surprisingly path dependent. Higher environmental protection decisions issued by FERC in the year before a particular license comes up for review lead to significantly less environmental protection on wholly unrelated licenses in the following year. It is as if FERC is trying to "balance" the environmental protection/hydropower production trade-off year by year.

These results from past licensing decisions should help us predict how future licensing decisions will likely proceed. Even more importantly, these results imply that if the current allocation of surface water in the Unites States between its competing end uses is found to be inefficient, the most effective way to alter the current allocation is by passing new legislation or by implementing institutional reform at FERC. This suggests that, despite the increasing attention given in the literature to interest group effects on regulatory behavior (Mitchener 2007; Knittel 2006; Li, Qiang, and Xu 2005; Aidt 2002; Oates and Portney 2001), interest group lobbying is not as influential in affecting regulatory behavior (at least in this context) as direct congressional action.

\section{BACKGROUND}

\section{The History of FERC ${ }^{\mathrm{l}}$}

The federal government took its first legislative interest in monitoring the development of the nation's riverine resources in 1899 when it passed the Rivers and Harbors Act, which recognized the interstate nature of river flows and the need for coordinated economic development of these resources at a federal level. Energy generation was at the core of the nation's burgeoning prosperity, and hydropower production was just one important and growing subset of that core industry. In the late 1800 s permits for hydroelectric production were still being issued by the Secretary of War, with the

\footnotetext{
${ }^{1}$ This historical summary draws on the one published by Kosnik (2006),
} 
ultimate regulating authority over hydropower development resting with the Department of War, but by 1920 hydropower generation had reached 20 billion kilowatt hours of electric power per year (from an operating capacity of $4,800 \mathrm{MW}$ ), and the nation's appetite for hydroelectric production was still far from satiated. There was a clear need for the creation of a more coordinated and centralized federal regulatory authority focused specifically on hydropower development issues.

In 1920 Congress passed the Federal Water Power Act, which was later replaced by the 1935 Federal Power Act, to streamline the administrative processes involved in hydropower regulation and to create a single regulatory agency focused entirely on developing and encouraging hydropower production in the United States. Today, that agency is known as the Federal Energy Regulatory Commission (FERC).

It was not until the late 1960s and early 1970 s, as society's preferences for protection and enhancement of environmental resources developed, that legislation was passed that changed FERC's mandate from an exclusive focus on hydropower production, to an incorporation of protection for a river's unique ecosystem. Prominent among this new legislation was the National Environmental Policy Act of 1969, which identified environmental protection as a major policy objective for the federal government. For FERC, this new act meant that an environmental assessment had to be filed for every hydropower permit requested, often leading to changes in the permit issued in order to protect environmental interests. In 1972, the Clean Water Act prohibited the discharge of pollutants into most waterways of the United States. For FERC, this legislation translated into a requirement for state certification of clean water at the project site before either an initial license or a relicense could be issued. In 1973, the Endangered Species Act provided a legislative foundation for protecting and conserving endangered and threatened species and their associated habitats. For FERC this translated into an assessment requirement to determine whether a hydroelectric project would affect any threatened or endangered species or their habitat, and often subsequent requirements to alter hydroelectric production to protect any identified species. Additionally, it required FERC to consult with the Fish and Wildlife Service or the National Marine Fisheries Service in determining the impact of any hydropower project on any at-risk species. In 1986 Congress passed the Electric Consumers Protection Act (ECPA), the first piece of legislation since 1935 to directly amend the Federal Power Act. This important act required that "in addition to the power and development purposes for which licenses are issued, [FERC] shall give equal consideration to the purposes of enhancement of fish and wildlife (including related spawning grounds and habitat), the protection of recreational opportunities, and the preservation of other aspects of environmental quality."2

These acts, as well as others, forced FERC to formally open up the regulatory process and involve commentary from outside resource agencies and interest groups. This interaction between FERC and outside agencies in the regulation of the hydroelectric industry led to new requirements, now attached to the end of licenses issued, that limit water flow and hydroelectric production in return for environmental enhancements such as improved water quality, increased aquatic resources, and protected wildlife and vegetation. FERC now regularly seeks to balance power and environmental objectives in its hydropower licensing process, the administrative details of which are explained in the next section.

\section{Issuing a Hydroelectric Dam License}

In the United States today, there are over 79,000 working dams. Most of these are small structures with a crest elevation of less than 50 feet and little to no hydroelectric

\footnotetext{
${ }^{2}$ Section 4(e) of the Federal Power Act, as amended by the ECPA.
} 
generation. Of the larger dams that remain, some are federally owned (the most familiar include the Hoover Dam, the Grand Coulee Dam, and the Shasta Dam) and the rest are nonfederal or privately ${ }^{3}$ owned dams. The nonfederal dams that generate hydropower come under the regulating authority of FERC, which since 1935 has issued thousands of licenses, all of which are for a term of 50 years or less. At the end of an initial license period, the dam owner must file for a relicense, again not to exceed 50 years, in order to legally continue operation. ${ }^{4}$ As the apex of nonfederal dam building took place after World War II, and many of these dams received initial 50 year license terms, it so happens that many dams are currently up for relicensing. For example, in 1983, fewer than 10 dams were up for relicensing before FERC, while in 1993, 157 dams came up for relicensing. Additionally, between 1998 and 2010, more than a third of all nonfederal hydropower dams, affecting over 100 different rivers, have come up for relicensing.

Currently, there are three different procedural methods for acquiring a hydroelectric license. The oldest and by far the most common method for acquiring a new license is through the traditional licensing procedure (TLP). This licensing process takes place in four rough stages (Figure 1). ${ }^{5}$ The first step (Stage 1) is for the prospective dam owner, or licensee, to file an official notice of intent to seek a license with

\footnotetext{
${ }^{3}$ While nonfederal dams are commonly labeled as "private," this is somewhat misleading as many nonfederal dams are in fact owned by local or state governmental entities. For example, the Azusa Dam on the San Gabriel River in California is owned by the city of Pasadena. The key is that they are nonfederal and so come under the jurisdiction of FERC.

${ }^{4}$ Note that as a result of the 1984 Supreme Court decision in Yakima Indian Nation v. The Federal Energy Regulatory Commission (746 F. 2d. 466), "relicensing is substantially equivalent to issuing an original license." In other words, procedurally FERC is supposed to approach new license applications and relicense applications in essentially the same manner; we test for whether this is so with a dummy variable on new license applications in our empirical regressions.

${ }_{5}$ Details of this process have been published by FERC (2004).
}

FERC. ${ }^{6}$ Concurrent with the filing of the notice of intent, technical information regarding the project is required, including all known and "reasonably" available engineering, economic, and environmental information. After submission of these materials, tentative impact studies are carried out as the licensee begins to prepare the licensing package. Approximately three years later (Stage 2), the prospective dam owner then submits an official licensing application, which FERC reviews, approves, and then formalizes with a notice in the Federal Register. It is most commonly at this point in the TLP (Stage 3) that interest groups concerned with a particular licensing application become involved in the process by submitting comments, protests, and official requests for information and/or studies. The licensing process is the only official opportunity during the lifetime of a dam for a complete review of its safety operations and environmental effects. It is also the only opportunity for interest groups and concerned individuals to influence the operations of the dam through FERC's formal regulatory process. Negotiations between the dam owner and the resource agencies should be worked out during this phase, and either an environmental assessment or an environmental impact statement must also be completed at this juncture.

The final step (Stage 4) of the licensing process is scheduled to occur two years later when FERC holds a hearing regarding the licensing application and issues its regulatory decision. FERC has three options, it can (1) license a project for a term ranging anywhere from 30 to 50 years, (2) not issue a license (if it is an original license application) or have the project decommissioned (if

\footnotetext{
${ }^{6}$ Prefiling consultations (before Stage 1 begins) may take place between the licensee, FERC, and public resource agencies, in order to get a feel for the necessary studies and information that a license package will require, but this is not required, nor common, with the TLP. Part of the purpose of creating alternative licensing procedures, which are discussed below, was to formalize and encourage this prefiling stage and make early consultation and collaboration with outside agencies an integrated part of the licensing process.
} 


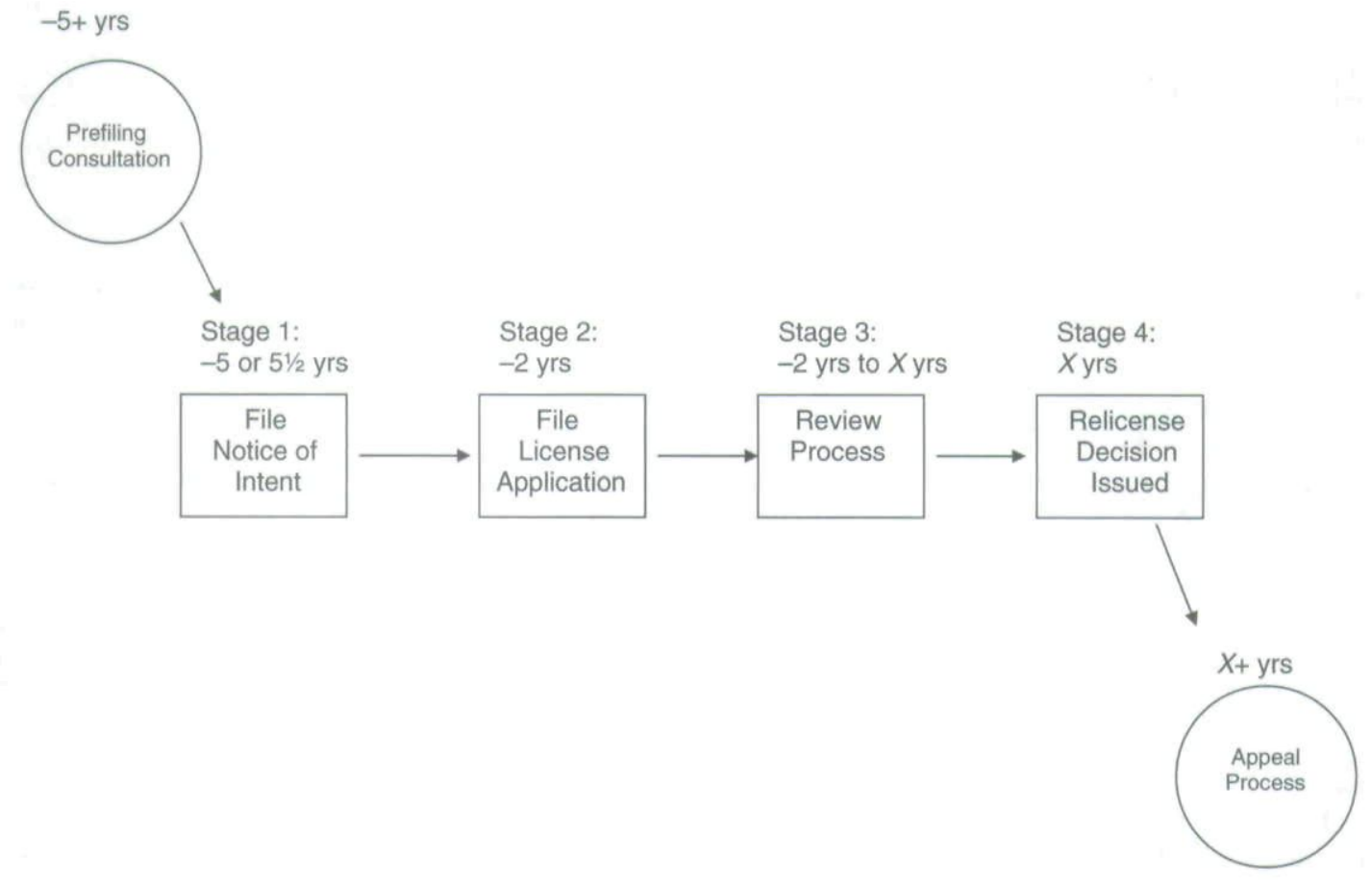

FIGURE 1

IsSUING A Hydroelectric Dam License

it is a relicense), or (3) recommend a federal takeover of a project (with compensation given to the current owner) and have it operated by the government.

An additional stage in the relicensing process can take place if one of the official intervenors to the relicensing process chooses to appeal FERC's relicensing decision. In such an instance, a review of the decision is conducted by the five FERC head commissioners. Barring finality of that decision, the last word is reserved for the U.S. Court of Appeals.

In 1998, due to increasing delays in the TLP process ${ }^{7}$ and contention among many of the stakeholders involved in the licensing process, FERC instituted the alternative licensing procedure (ALP). Procedurally,

${ }^{7}$ As outlined in Figure 1, the TLP is expected to average five years to completion, but in the 1990s this process began to get drawn out (Kosnik 2006), with some licenses taking as long as 20 years to be issued. the ALP involves the same steps as the TLP, but it is distinguished by at the same time actively encouraging collaboration and prenegotiation among the stakeholders. Use of the ALP is specifically designed to increase communication early on in the process (well before Stage 3) so that ultimate outcomes are less contentious, more politically legitimate, and issued with less delay. Settlement agreements among the interest groups and the dam owner, for example, are heavily promoted. Between 1998 and 2005 the ALP was chosen for use over the TLP 34 times.

While the ALP has, for the most part, been successful in its primary aims of decreasing licensing times and increasing stakeholder collaboration, use of the procedure is limited. Acceptance of the ALP requires special FERC approval, and this is not granted if the parties to the process cannot agree ahead of time as to the success of the collaborative nature of the proce- 
dure. Additionally, deadlines are not specific in the ALP, but defined by the group, and this has the potential for managerial and procedural difficulties. In the historical progression of the dam licensing process, the ALP is best viewed as a trial phase in reform of the TLP, as a side step along the way of reforming the TLP into what, since 2005, has become the new default licensing procedure, the integrated licensing process (ILP).

While the ALP and the TLP can still be utilized upon FERC approval, the ILP has become the default licensing procedure. It marries the structure of the TLP with the collaborative negotiating encouragement of the ALP. Procedurally, it involves the same rough outline as illustrated in Figure 1, with official deadlines and publications in the Federal Register, but now the preconsultation phase is formally integrated into the entire process. Stakeholder involvement is now required as early as Stage 1, instead of expected only after Stage 2. Similarly, at an advisory level, FERC involvement begins in Stage 1, and the entire process is navigated with a heavy emphasis on overall collaboration, negotiation, and consultation.

Reform of the licensing process from an exclusive utilization of the historical TLP, to development of the ALP and ILP alternatives, was a major procedural shift for FERC; as significant in its own way as passage of the ECPA more than a decade earlier. These two structural shifts were the two most fundamental reforms to the hydroelectric licensing regulatory process in its 75-year history.

\section{The Hydroelectric Power Industry}

The hydroelectric power industry is characterized by the fact that new construction of hydropower dams, as well as final retirement of older hydropower dams, has essentially stalled in the United States. Since the 1980 s, the stock of nonfederal hydropower dams has been fundamentally static.

Figure 2 shows the annual figures for total dam storage capacity in the United

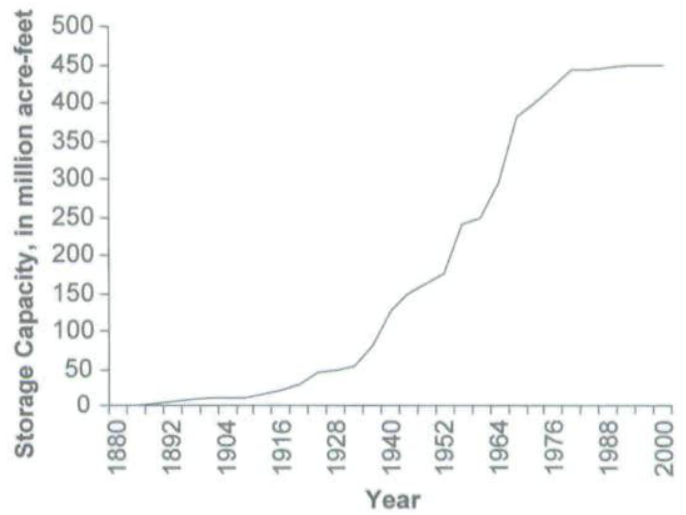

FIGURE 2

Reservoir Storage CAPACITY IN THE United States, 1880-2000

SOURCES: Alley, Reilly, AND

FranKe 1999; ANDERSON AND WoOsLey 2005

States from 1880 until 2000; this graph makes clear the history of dam construction from its initial viability and take-off around the turn of the twentieth century, until its stagnation around the early 1980s. Since that time there have been very few new dams (of any type) constructed anywhere in the United States. ${ }^{8}$ This has occurred for two primary reasons: first, there simply are no more viable sites containing the necessary technical requirements (ground strength and narrow river bank, for example) for sound dam construction, and second, even in the few areas along our nation's navigable rivers where new dams might conceivably be built, environmental constraints and regulations have limited the political viability of any new construction. This is particularly true for hydropower dams, which cause harm not just from the interruption of river flow, but from the mechanized turbines that generate the electricity and entrap and kill fish attempting to pass through them. Even the National Hydropower Association, the official trade group for the nonfederal hydropower industry, admits that any

${ }^{8}$ Only $4.1 \%$ of the observations in our 1983-2005 dataset, for example, are for new dam construction; the vast majority are relicenses. 
future increase in hydropower production in the United States can only come from technological improvements to existing hydropower stock, not from the construction of any new large dams. ${ }^{9}$

Similarly, not many existing dams have been retired in recent decades. In FERC's 75 -year history, only once has it ordered the decommissioning of a dam. ${ }^{10}$ While a few dams have been voluntarily surrenderedinstead of ordered for decommission by FERC - the number of such instances is astonishingly small. This is because hydropower dams are, essentially, cash cows. The main cost of hydroelectric power is the initial construction costs of building a large dam and reservoir. Once a dam exists, its maintenance and operation costs are minimal. Compared to other forms of generating power, where conversion rates of energy into electricity average $50 \%$ or less, hydroelectricity has an efficiency conversion rate of $90 \%$-better than any other form of generation. Existing hydroelectric power plants are therefore extremely cost-effective. With rising energy prices in recent years, the returns to the hydropower produced have only increased.

Therefore, when a hydropower project comes before FERC for a relicense, the request is almost inevitably granted. The regulatory issue is rarely whether or not to issue a license at all, it is, in issuing a license, how many environmental requirements to mandate alongside the license issuance. Because there are only so many end uses to which any single river can be allocated (endangered species protection, recreational use, aesthetic concerns, for example), it is FERC's job to balance the competing demands when issuing a license and its accompanying requirements. This research will help to shed light on the mandates that

\footnotetext{
${ }^{9}$ Although technical improvements to the existing hydropower stock could potentially yield as much as $50 \%$ more capacity (U.S. DOE 2006; Veltrop 1997).

${ }^{10}$ In 1997 FERC denied a license to the Edwards Dam, on the Kennebec River near Augusta, Maine, and ordered that it instead be removed through federal takeover.
}

accompany a hydropower license, including what types of factors influenced how many were ultimately chosen. This will help us understand how FERC has interpreted its regulatory mandate in the past, which should help us anticipate how other relicensing proposals will proceed in the future.

\section{FRAMEWORK}

The influences on regulatory agency decision making are still debated in the literature. An early assumption, which in recent years has made something of a comeback, was that regulators sought to maximize the public welfare, and in issuing regulatory decisions had the independence and discretion to pursue a "public-interestdriven" policy. Today this assumption by itself appears naïve, but as at least a component of regulatory agency decision making (Crone and Tschirhart 1998; Nowell and Tschirhart 1993), ideology and discretion have been found in many studies to have empirical support. Olson (1995, 1997, 2000) and Dranove and Meltzer (1994), for example, both found that the Food and Drug Administration (FDA) moved drugs along the regulatory pipeline in part based on a drug's perceived importance. Ando (2001), Cropper et al. (1992), Magat, Krupnick, and Harrington (1986), and Yaffee (1982), in different contexts, all found that Environmental Protection Agency (EPA) regulatory decisions have been influenced by independent bureaucratic discretion. And Bartel and Thomas (1987) have found the same discretionary effect with regards to Occupational Safety and Health Administration regulations. Discretion on the part of the regulator, it should be noted, may not necessarily imply benevolence, but it does at a minimum imply the independence to pursue a possibly ideological agenda.

A significant challenge to the public interest view of regulatory agency decision making came with the seminal works of Stigler (1971), Peltzman (1976), and Becker (1983). "Regulatory capture theory,"' as it is 
known, implies that regulators are beholden to interest groups (either for political support, votes, funds, or future job opportunities), and so they make decisions based on the outcome of interest group lobbying, in a manner to maximize overall interest group support. Empirical evidence in support of this theory, for agencies as diverse as the FDA, the EPA, and the National Forest Service, has been found in research by Carpenter (2002), Sigman (2001), Ando (1999, 2001), Crone and Tschirhart (1998), Sabatier, Loomis, and McCarthy (1995), Nowell and Tschirhart (1990), Cropper et al. (1992), and Yaffee (1982).

A third strand of the literature focuses on bureaucratic agency decision making as influenced by congressional control. "Congressional dominance theory," as it is called, suggests that agencies are not independent but are reliant on congressional support either because of budget appropriations, oversight, or threatened legislation. An important influence on regulatory decision making then should be members of Congress and the actions they impose. Olson (1995), Anderson (1993), Helland (1999), Gilligan, Marshall, and Weingast (1989), McCubbins, Noll, and Weingast (1987), and Weingast and Moran (1983) have all found evidence for this effect at the FDA, the International. Trade Commission, the Interstate Commerce Commission, and other regulatory agencies. ${ }^{11}$

Finally, most recently in the literature, a few voices have been heard suggesting that history, or the status quo starting point, is important for understanding bureaucratic agency decision making. As Beard, Kaserman, and Mayo (2003, 594) note, "The location of the unregulated equilibrium and other prior market parameters provide the principal constraint on the regulator's ability to deliver ... through regulation." This argument echoes behavioral theories

\footnotetext{
${ }^{11}$ Spence (1997) and Wood (1988) are two researchers who provide contrary evidence that regulators are relatively immune to input or oversight from Congress.
}

about the importance of "endowment" or "starting point" for subsequent decision making. Indeed, Sabatier, Loomis, and McCarthy (1995) give evidence that Forest Service planning decisions regarding output targets for timber and other resources have been heavily influenced by existing (or "historical") output levels. ${ }^{12}$ But this is new in the literature. Empirical tests of the validity of such historical effects are common in individual-level behavioral studies, but this paper appears to be the first to include such variables in regressions of regulatory behavior.

In the following model we assume the regulator attempts to maximize a utilitybased objective function in implementing regulatory policy, and that all of the above factors (discretion $D$, interest groups $I$, Congress $C$, and history $H$ ) may be influential in affecting utility:

$$
U=U(D, I, C, H) \text {. }
$$

Discretion brings utility to the regulator by allowing the regulator to follow through on personally held beliefs, goals, or interests, and by minimizing any cognitive dissonance on the job. Interest groups bring utility to the regulator through political support, votes, positive public-relations campaigns, and other political activities. Congress brings utility by limiting its oversight and by granting greater budget appropriations. And history affects utility through a starting point bias (Kahneman and Tversky 1979), often related to institutional constraints (North 1990).

In the context of hydroelectric power regulation, the regulator maximizes total utility from these factors when achieving a balance between hydroelectric power production $(P)$ and environmental riverine protection $(E)$, per license:

$U=U[D(E, P), I(E, P), C(E, P), H(E, P)]$.

\footnotetext{
${ }^{12}$ Even Peltzman $(1976,222-24)$ in his influential article on regulatory behavior suggests defining his equations "with respect to an anarchistic reference point."
} 
Due to the physical nature of hydropower production, environmental protection generally comes at the cost of reduced hydropower capacity (Kotchen et al. 2006; Edwards, Flaim, and Howitt 1999; FERC 1991). For example, FERC could require dam owners to limit the flow of water through the dams' turbines. This would reduce electricity production, but it would also help eliminate irregular rushes of water that cause stream bank erosion and damage to aquatic nesting sites. Other methods FERC could impose to help the riverine environment (such as fish ladders, modified turbines, etc.) similarly tend to negatively affect electricity production. In the end, when FERC issues a license mandating a certain number of environmental requirements, it is implicitly choosing a certain trade-off between environmental protection and hydropower production. The issue for FERC is to decide just how many environmental mandates to issue per license, and how to balance the trade-off. Therefore, either $E>0$ and $P<0$ or $E<0$ and $P>0$. In other words,

$$
\begin{aligned}
& U=U[D(E, P), I(E, P), C(E, P), H(E, P)] \\
& \text { s.t. } E=f(p) \text { and } f^{\prime}<0 .
\end{aligned}
$$

FERC achieves the balance between $E$ and $P$ in setting the specific number of environmental requirements mandated per license. The number of mandated requirements is analogous to setting the price, tariff, or subsidy level in other regulatory models (see, e.g., Becker 1983 or Beard, Kaserman, and Mayo 2003). Comparative statics can then be derived on the relative effects of discretion, interest groups, congress, and history on the total number of requirements mandated per license.

\section{DATA}

From 1983 to 2005 FERC issued 498 new hydroelectric licenses. ${ }^{13}$ Data were gathered on these projects from a number of sources

\footnotetext{
${ }^{13}$ A single license can authorize one, or more than one, hydroelectric dam at a time.
}

including the licenses themselves, the license docket sheets (a formal recording of all the paperwork submitted during the licensing process), an internal FERC database on the technical and physical characteristics of each of the projects, and public and governmental records on relevant political and river basin characteristics. ${ }^{14}$ Summary statistics are provided in Table 1.

The dependent variable in our analysis is the number of environmental requirements issued by FERC for each license application. It is through these requirements that FERC carries out its contemporary mandate to balance both power and nonpower objectives when issuing a new hydropower license. FERC has issued anywhere from zero to over 30 such requirements per application (Figure 3), implying significant heterogeneity in ultimate outcomes. A representative sample of these requirements can be found in Table 2. Not all requirements constrain hydropower production in the same manner or to the same degree, but they are all designed to limit hydropower capacity somewhat. It is true that a more calibrated model would weigh each requirement in association with its degree of effect on hydropower capacity, but determining such a weighting scale, given the rather limited technical information provided in a license, is not at all straightforward. Attempts to do so could be made on a variety of levels, leading to a degree of subjectivity in the results that the author wishes to avoid. It is left to future research, therefore, to find a way to extend the current model to account for not just number, but type, of environment requirements and its more specific associated degree of constraint on hydropower capacity.

The explanatory variables are grouped into four categories, following our four factors of influence on FERC's objective function: $D, I, C, H$.

\footnotetext{
${ }^{14}$ The final number of observations used in later regressions is less than 498 because of random missing data on different observations from any one of the abovelisted sources.
} 
TABLE 1

Summary Statistics

\begin{tabular}{|c|c|c|c|c|}
\hline Variable & Mean & Std. Dev. & Min. & Max. \\
\hline \multicolumn{5}{|l|}{$\begin{array}{l}\text { Dependent Variable } \\
\text { Total environmental } \mathrm{r}\end{array}$} \\
\hline Independent Variables & 10.37 & 5.44 & 0 & 35 \\
\hline $\begin{array}{l}\text { Dam height } \\
\mathrm{kW} / 0^{3} \\
\text { Electricity price } \\
\text { East } \\
\text { West } \\
\text { Rivermile } \\
\text { Endangered river } \\
\text { Private owner } \\
\text { Multiple owner }\end{array}$ & $\begin{array}{r}44.92 \\
24.15 \\
7.71 \\
0.78 \\
0.20 \\
233.28 \\
0.09 \\
0.39 \\
4.52\end{array}$ & $\begin{array}{r}62.59 \\
112.27 \\
2.05 \\
0.42 \\
0.40 \\
1,183.07 \\
0.28 \\
0.49 \\
5.07\end{array}$ & $\begin{array}{l}0 \\
0 \\
3.90 \\
0 \\
0 \\
0 \\
0 \\
0 \\
0\end{array}$ & $\begin{array}{c}632 \\
2,000 \\
13.43 \\
1 \\
1 \\
21,110 \\
1 \\
1 \\
18\end{array}$ \\
\hline Intervenors & 10.62 & 7.55 & 0 & 39 \\
\hline $\begin{array}{l}\text { Sportsfishing } \\
\text { Boating } \\
\text { Historical } \\
\text { Endangered species } \\
\text { Water quality } \\
\text { Recreation } \\
\text { Federal } \\
\text { State } \\
\text { Local } \\
\text { Public } \\
\text { Private } \\
\text { NGO }\end{array}$ & $\begin{array}{l}4.88 \\
0.39 \\
0.71 \\
5.48 \\
4.77 \\
1.07 \\
4.63 \\
4.07 \\
4.26 \\
7.12 \\
1.23 \\
4.7\end{array}$ & $\begin{array}{c}3.33 \\
0.91 \\
0.95 \\
3.64 \\
3.34 \\
1.39 \\
3.2 \\
2.89 \\
21.76 \\
4.38 \\
1.8 \\
22.03\end{array}$ & $\begin{array}{l}0 \\
0 \\
0 \\
0 \\
0 \\
0 \\
0 \\
0 \\
0 \\
0 \\
0 \\
0\end{array}$ & $\begin{array}{r}16 \\
7 \\
5 \\
18 \\
18 \\
8 \\
16 \\
19 \\
28 \\
27 \\
19 \\
16\end{array}$ \\
\hline $\begin{array}{l}\text { LCV score } \\
\text { Senate committee } \\
\text { ECPA } \\
\text { Relicense } \\
\text { History } \\
\text { ALP }\end{array}$ & $\begin{array}{c}0.56 \\
0.33 \\
65 \\
0.93 \\
8.91 \\
0.06\end{array}$ & $\begin{array}{l}0.29 \\
0.47 \\
0.48 \\
0.26 \\
3.10 \\
0.24\end{array}$ & $\begin{array}{l}0 \\
0 \\
0 \\
0 \\
3 \\
0\end{array}$ & $\begin{array}{c}1 \\
1 \\
1 \\
1 \\
13.9 \\
1\end{array}$ \\
\hline \multicolumn{5}{|c|}{ Sociodemographic Variables } \\
\hline $\begin{array}{l}\text { Population } / 10^{3} \\
\% \text { age } 0-24 \\
\% \text { age }>75 \\
\% \text { bach. degree } \\
\text { Median income } 10^{3} \\
\% \text { below poverty } \\
\text { Housing units } / 10^{3} \\
\text { Labor force } 10^{3} \\
\text { Unemployed } 110^{3} \\
\text { Total farms } \\
\text { Manf. earnings } / 10^{3} \\
\text { Gov. revenuel } 10^{3}\end{array}$ & $\begin{array}{r}140.18 \\
34.97 \\
5.52 \\
15.13 \\
28.14 \\
10.90 \\
54.86 \\
68.99 \\
4.46 \\
742.38 \\
260.84 \\
152.31 \\
\end{array}$ & $\begin{array}{r}423.64 \\
9.01 \\
2.18 \\
6.07 \\
9.18 \\
3.75 \\
148.26 \\
208.71 \\
13.8 \\
766.19 \\
680.31 \\
366.37\end{array}$ & $\begin{array}{l}1.14 \\
0 \\
0 \\
5.4 \\
10.97 \\
2.4 \\
0.93 \\
0.55 \\
0.02 \\
0 \\
0 \\
0.01\end{array}$ & $\begin{array}{c}8,295.9 \\
56.5 \\
12.1 \\
42.1 \\
57.81 \\
25.6 \\
2,855.58 \\
4,095 \\
273 \\
7,590 \\
6,798.76 \\
3,859.49\end{array}$ \\
\hline
\end{tabular}

\section{Discretionary Explanatory Variables}

We assume that if FERC wishes to exhibit discretion in a relicensing application, it does so according to the type of project up for relicensing. For example, if FERC is predisposed to the hydropower production potential of a dam (as opposed to protecting the riverbed it is built upon), then FERC might issue fewer requirements for larger dams, or those that produce more valuable electricity, in more valuable regions of the country. Dam height, measured in feet, is an indicator of the size of a 


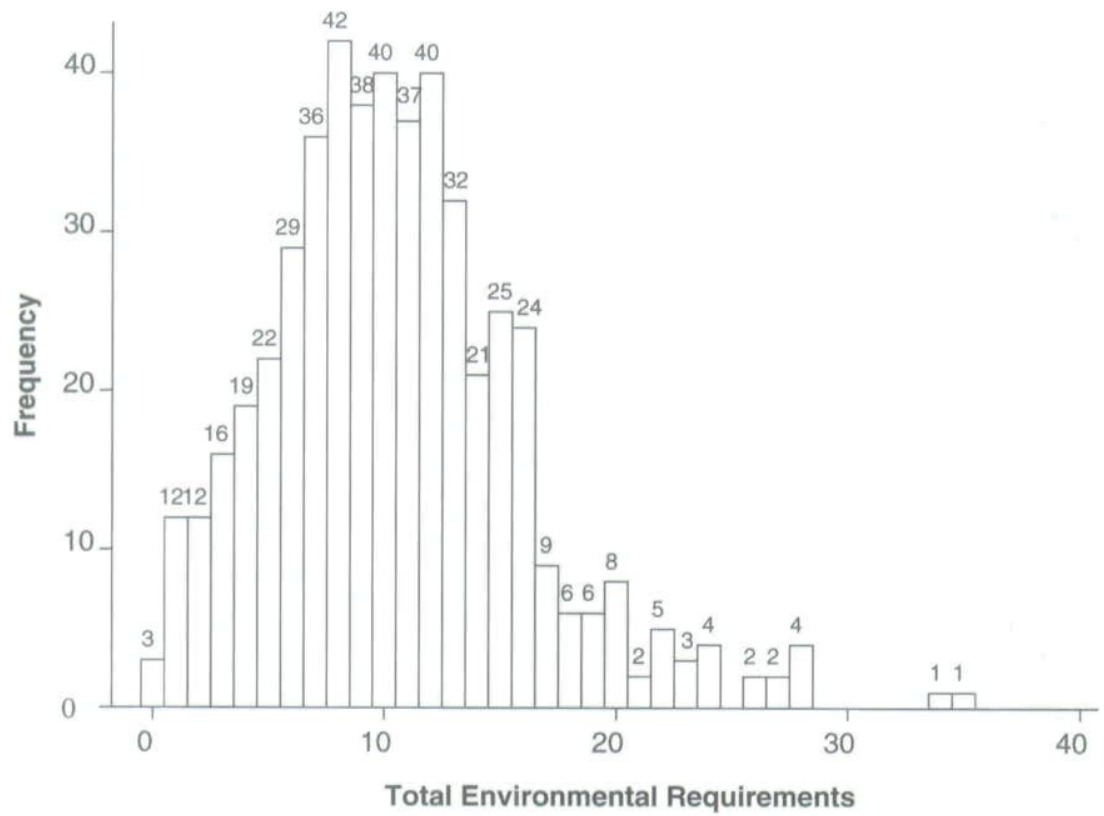

FIGURE 3

Total ENVIRONMENTAL REQUIREMENTS

project. ${ }^{15}$ Similarly, $k W$, which measures the available kilowatt production capacity at a project, is a second size/production indicator. Electricity price, meanwhile, is the average residential price of electricity (in cents) per kilowatt-hour, for the state in which the project is located, in the year it applies for a license. ${ }^{16}$ And East and West, dummy variables indicating whether the power produced at a dam is transmitted through the western U.S. power grid or the

\footnotetext{
${ }^{15}$ For projects with more than one dam, average dam height, maximum dam height, and total of all dams' height were tried as regressors, with similar ultimate results. The regressions reported in the following tables utilize tallest dam height. In Table 1, the minimum value for Dam height is zero. This is not an error. Rarely, a project can have a zero recorded dam height either because (1) the project is a low-impact run-of-river hydroelectric facility that generates power as the river flows, but without much of an official diversion structure; or (2) because the nonfederal hydroelectric facility is utilizing a diversion structure owned by some other entity (for example, a municipal water supply system); in this case because the dam structure is not owned by the licensee, it is not officially a part of the hydro project as licensed by FERC. 1970.

${ }^{16}$ As deflated by the Consumer Price Index, base year
}

eastern U.S. power grid, are our geographic indicators. ${ }^{17,} 18$

If, on the other hand, FERC's ideological bias is in the environmentally friendly direction, then we would assume that larger dams might receive more environmental requirements, all else equal, and that dams built on longer or more unhealthy rivers would also receive more requirements after controlling for other factors. Rivermile measures the total river miles of all the dams (creating their respective reservoirs) in the project, and Endangered river is a dummy variable used to indicate the base environmental health of a river on which a project is located. Endangered river indicates whether the river is listed as threatened/endangered in the year the project applied for a license. ${ }^{19}$

\footnotetext{
${ }^{17}$ The default alternative is an independent power grid in Texas, Alaska, or Hawaii.

${ }_{18}$ These power grids are distinct and have limited interconnections with each other, and while we have no priors concerning the signs of the coefficients between these two variables, it may be that electricity is more valuable on a particular transmission grid.

${ }^{19}$ As assessed by the national organization American Rivers (www.amrivers.org).
} 


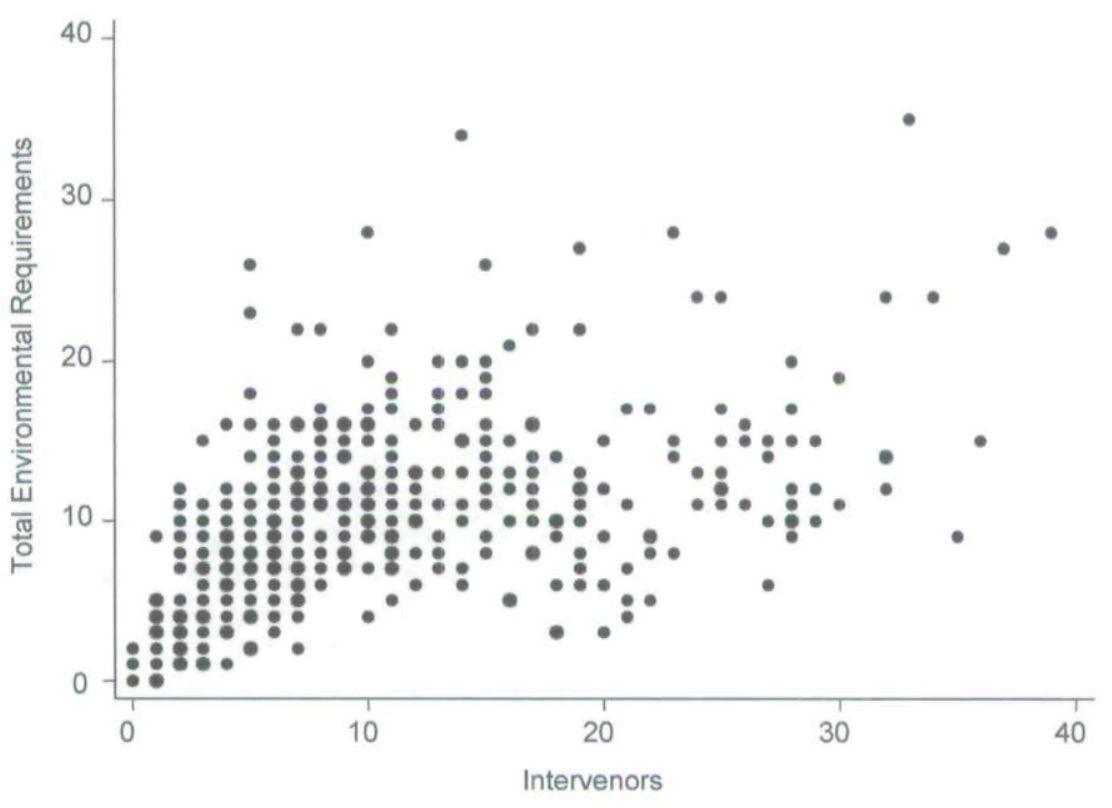

FIGURE 4

CORRELATION OF INTEREST Group INVOLVEMENT WITH TOTAL ENVIRONMENTAL REQUIREMENTS ISSUED

Because FERC's initial 1935 mandate was written specifically to encourage hydropower production, and because it was only altered to directly consider environmental objectives as late as 1986, many

\section{TABLE 2}

TYPES OF MANDATED

ENVIRONMENTAL REQUIREMENTS

\begin{tabular}{|c|c|}
\hline License \# & Abbreviated Description \\
\hline P-2520 & Install upstream fish passage facilities \\
\hline P-2436 & Protect shoreline from erosion \\
\hline P-2512 & Operate project in a run-of-river mode \\
\hline P-618 & Minimum flow releases of $x$ required \\
\hline P-663 & $\begin{array}{l}\text { Protect habitat aquatic species populations in } \\
\text { the bypassed reach }\end{array}$ \\
\hline P-1979 & Drawdown rates of reservoir limited to $x$ \\
\hline P-2302 & Implement a water quality plan \\
\hline P-1953 & Monitor dissolved oxygen levels \\
\hline P-2323 & Limit the maximum change in ramping rates \\
\hline P-1388 & $\begin{array}{l}\text { Revegetate disturbed areas with plant species } \\
\text { beneficial to wildlife }\end{array}$ \\
\hline P-2496 & $\begin{array}{l}\text { Modify fish ladders so as to enhance } \\
\text { anadromous fish migration }\end{array}$ \\
\hline P-1267 & $\begin{array}{l}\text { Manage and protect all historic properties on } \\
\text { site }\end{array}$ \\
\hline P-308 & $\begin{array}{l}\text { Minimum flows required into the bypassed } \\
\text { reach }\end{array}$ \\
\hline
\end{tabular}

believe that FERC still acts with a latent bias-left over from this historical tradition-in favor of hydropower production. If the coefficients on the seven discretionary variables are significant, they may confirm that FERC does, or does not, hold such a pro-power bias.

\section{Interest Group Explanatory Variables}

The hydropower licensing debate can be characterized as a standoff between hydropower interests and environmental interests. The hydropower side is represented, for the most part, by the dam owner. We have two explanatory variables that give us an indication of the type of dam owner involved in a project licensing. Private owner is a dummy variable indicating that the owner is a private utility company, as opposed to the dam being municipally owned, owned by a nonutility (also known as a generation company), or owned by a cooperative (for example, by an Indian tribe). The second firm ownership variable, Multiple owner, is a measurement of the size of the firm owner. Large firms generally 
own more than one project and thus often have multiple licensing experiences with FERC. Owners of large revenue-generating projects are also often heavily invested in hydroelectric generation and may be even more strongly opposed than other types of owners to alternative allocative uses of the project's waters. This variable is a count of the number of other projects simultaneously owned by a particular licensee. If the coefficients on both of these variables are significant and negative, it would indicate that larger, privately owned utilities are better able to capture a less stringent relicensing mandate from FERC.

Environmental interests are represented in the licensing process by advocacy groups who formally lobby the regulator. All interventions are posted on the license application's docket sheet, and from these docket sheets lists were tabulated, for each project, of all of the interest groups involved in the relicensing processes, as well as the number of times each representative group chose to comment (in order to capture the degree of their involvement, and not simply their presence). Intervenors is a count of the total number of these interest groups involved in each relicensing exercise. ${ }^{20}$ Figure 4 illustrates the correlation of Intervenors with the total number of environmental requirements mandated.

All kinds of interest groups tend to get involved in the process, ${ }^{21}$ from national to local level interest groups (American Rivers; Camp Grady Spruce), public and not-for-profit interest groups (California Boating and Waterways; Federation of Fly Fishers), and interest groups with advocacy interests that range from sportsfishing to water quality (California Trout; Idaho Department of Water Resources). In the empirical section Intervenors is broken

\footnotetext{
${ }^{20}$ Models were also estimated in the empirical section with count data on the total numbers of comments submitted, but as the results were similar to those of the models using Intervenors, in the interest of brevity we report only the latter results.

${ }^{21}$ See Kosnik (2010) for a look into what motivates an interest group to get involved in the process in the first place.
}

down by these additional category constructions to try to make more detailed inferences regarding the effects of specific types of environmental interest group activity on the number of ultimate licensing requirements mandated. Intervenors is broken down first by advocacy type: Sportsfishing, Boating, Historical, Endangered species, Water quality, and Recreation; then by geographic range: Federal, State, and Local; and finally by market orientation: Public, Private, NGO. See Table 3 for a list of intervenor descriptions and examples. By differentiating the intervenors by geographic range and by market type, for example, we explore whether intervenors with a larger membership base have more clout than purely locally based intervenor groups, and whether the market type of an interest group has any significant effect on regulatory clout. ${ }^{22}$

It is worthwhile to alert the reader early to the method by which the intervenor data was broken down when disaggregated by advocacy type. A few of the intervenors (though not enough to justify additional categories) were known to advocate on behalf of multiple interests (American Rivers, for example, is concerned with endangered species, water supply, and sportsfishing issues). When the data were tabulated, these multiadvocacy intervenors were counted in each of the categories to which their interests applied. Due to this construction, the reader should be forewarned of a degree of multicollinearity built in to the dataset, in particular, in the intervenor group data when it is disaggregated by advocacy type.

\section{Congressional Explanatory Variables}

The ability of the legislature to affect FERC's regulatory decisions was tested in three ways. $L C V$ score is the average League of Conservation Voters score for

\footnotetext{
${ }^{22}$ While it may be informative to differentiate these intervenor variables by geographic level and by advocacy type simultaneously, unfortunately doing so results in too few observations per category (of which in this instance there would be 27) to run any meaningful regressions.
} 


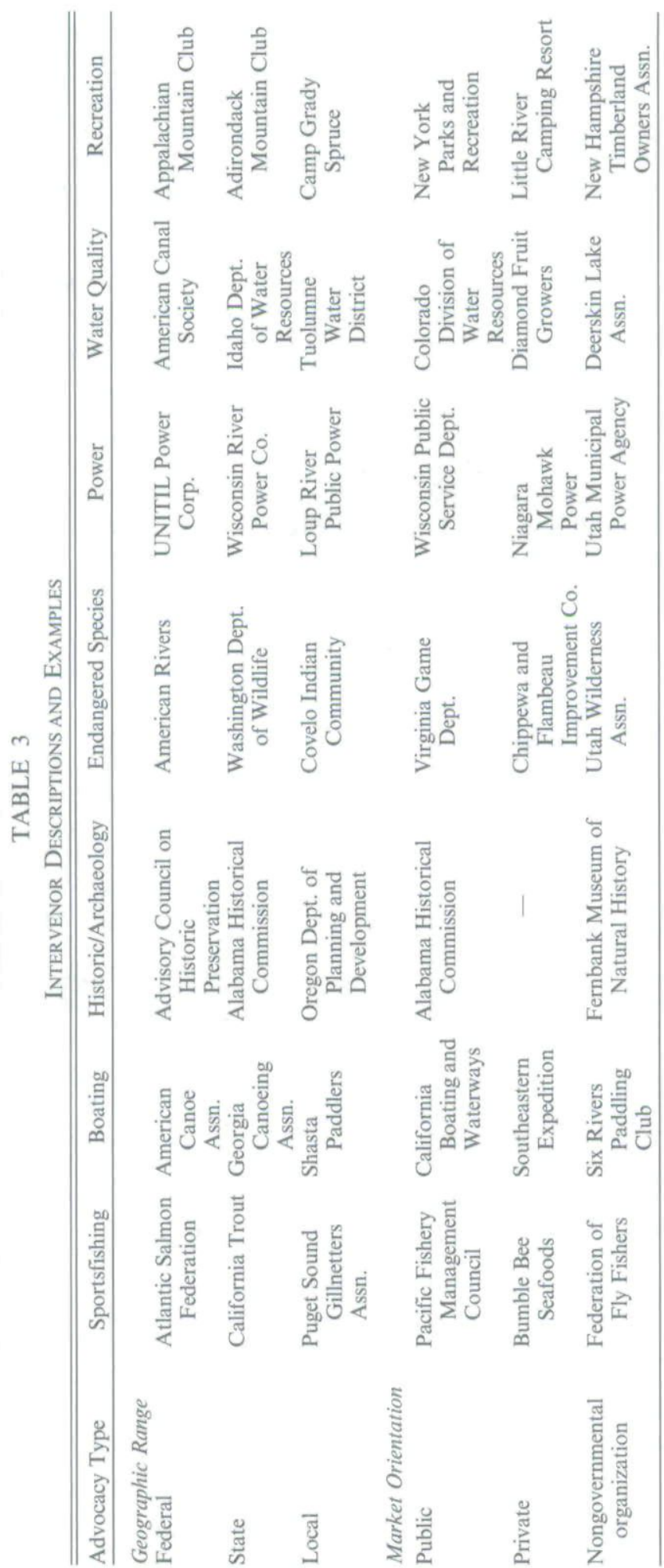


the two senators in Congress from the state within which a project is located, in the year that the project went up for licensing. It was included as a proxy for the "congressional mood" in Congress at the time of licensing. The idea is that, at different times or in different political environments, pressure from congressional representatives may have a varying effect on the regulatory agency. Specifically, if the mood in Congress is heavily Democratic and pro-environmental, then congressional pressure in support of environmental benefits, in such a setting, would lead to more environmental requirements mandated than if Congress were at that time dominated by more hydropower-supporting Republicans. The League of Conservation Voters score is a rating between 0 and 1 for environmental sensitivity ( 0 being none, 1 implying extreme environmental sensitivity). This rating is gleaned from the past voting records, on environmental issues, of each elected senator. Traditionally, Republicans have had lower League of Conservation Voters scores than Democrats, and eastern states have had much higher scores than western ones. $^{23}$

Senate committee is a dummy variable indicating whether at least one of the senators in a project's state, at the time of licensing, was a member of the oversight committee in charge of FERC. According to congressional control theories of regulatory capture, an individual senator who has direct congressional influence over FERC should be able to particularly influence the commission's regulatory decisions in his or her home state. The direction of that capture, however, is ambiguous. If dam owners are supremely adept at influencing congressional representatives, then we would expect the coefficient on this variable

\footnotetext{
${ }^{23}$ For example, for the year 2000 scorecard, Republicans in the Senate averaged a score of 0.12 , while Democrats averaged 0.79 . Meanwhile, eastern states posted the highest environmental scores - Rhode Island at 1 , Connecticut at 0.91 , New Jersey at 0.91 , Vermont at 0.88 , and Massachusetts at 0.88 - and western states the lowest, with Idaho, Wyoming, Alaska, Utah, and Oklahoma all posting scores of 0 .
}

to be negative, indicating decreasing regulatory stringency. If, on the other hand, pro-environmental pressures hold sway in congress, we would expect the coefficient on this variable to be positive, indicating an increasingly stringent regulatory environment.

Finally, we include a dummy variable, $E C P A$, which indicates whether a project was relicensed after the implementation date of the ECPA amendments (January 2, 1990). As the ECPA amendments were designed by Congress to increase FERC's proclivity toward environmentally friendly regulation, we would expect to see a significant increase in environmental requirements issued after the passage of this amendment. In other words, we would expect the coefficient on this variable to be positive.

\section{Historical Explanatory Variables}

The types of historical variables that theoretically could affect FERC's decision making do so either through a starting point effect (in other words, a tendency for FERC to favor, or unwarrantedly "grandfather," historical positions), or through institutional constraints (in other words, the defined bureaucratic structure within which FERC operates constrains decision making). The starting point effect is investigated through the variables Relicense and Histo$r y$, and the institutional constraint variable is $A L P$.

Relicense is a dummy variable indicating whether a particular application is for the licensing of older hydroelectric project works. As stated in Section II, very few new hydropower dams are being built anywhere in the United States, but as there are some, with this variable we test to see whether there is any significant difference in regulatory stringency between original licenses and relicenses. Note that there should not be. In 1984 in Yakima Indian Nation v. The Federal Energy Regulatory Commission (746 F. 2d. 466), the Supreme Court established the criteria under which a hydroelectric dam relicensing application 


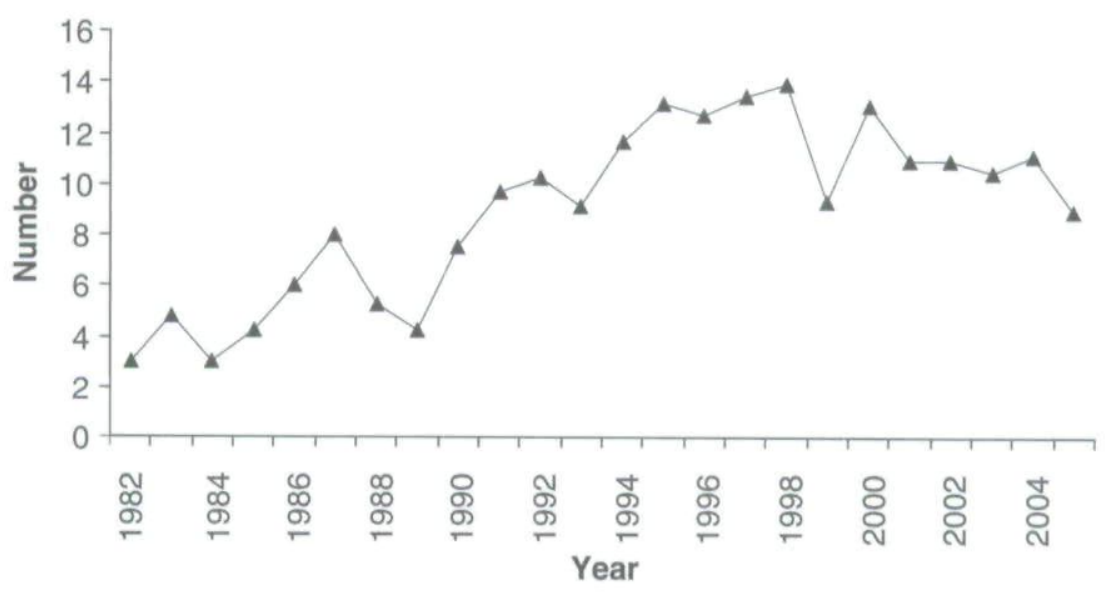

FIGURE 5

Average Number of EnVIronmental ReQuirements

should be considered. It determined that a relicensing application should be given the same scrutiny as an initial license application, with all the attendant requirements and regulation. There should be no grandfathering of older projects, in other words. "Relicensing," the Supreme Court stated, "is substantially equivalent to issuing an original license. ... Relicensing, then, is more akin to an irreversible and irretrievable commitment of a public resource than a mere continuation of the status quo. Simply because the same resources had been committed in the past does not make relicensing a phase in a continuous activity.

TABLE 4

Average Number of EnVIronmental REQUIREMENTS, BY YEAR

\begin{tabular}{lccc}
\multicolumn{4}{c}{ REQUIREMENTS, BY YEAR } \\
\hline \hline Year & Avg. & Year & Avg. \\
\hline 2005 & 8.96 & 1993 & 9.11 \\
2004 & 11.11 & 1992 & 10.23 \\
2003 & 10.42 & 1991 & 9.72 \\
2002 & 10.94 & 1990 & 7.54 \\
2001 & 10.9 & 1989 & 4.27 \\
2000 & 13.08 & 1988 & 5.29 \\
1999 & 9.36 & 1987 & 8 \\
1998 & 13.9 & 1986 & 6 \\
1997 & 13.45 & 1985 & 4.25 \\
1996 & 12.67 & 1984 & 3 \\
1995 & 13.14 & 1983 & 4.8 \\
1994 & 11.68 & 1982 & 3 \\
\hline
\end{tabular}

Note: Electric Consumers Protection Act went into effect in 1990.
Relicensing involves a new commitment of the resource."

The basis for the Supreme Court's interpretation stems from the initial legislative decision, in the Federal Water Power Act of 1920, to allow license terms for hydroelectric projects to last up to 50 years. During the debate at that time regarding how best to undertake development of the nation's rivers, there was disagreement over whether hydropower development should be a private or public enterprise. The compromise was to allow project license terms of up to 50 years, which was considered long enough time to allow a private developer to amortize the costs of any hydroelectric project, but at the same time would eventually return the water resources to the public domain where it could be determined anew how best to utilize them. In 1984 the Supreme Court concluded that when a dam then comes up for a relicense, it must be treated with essentially a blank slate. This can work in either the dam owners' or the environmental interest groups' favor, because it implies that nothing is off the table for historical reasons. We would expect the coefficient on Relicense, therefore, to be insignificant as there is no a priori reason to expect older dams to receive heavier or lighter regulatory burdens. Newer dams are presumably in more pristine areas, so a case could be made 
TABLE 5

DETERMINANTS OF THE NUMBER OF ENVIRONMENTAL REQUIREMENTS PER LICENSE

\begin{tabular}{|c|c|c|}
\hline Variable & Model 1 & Model IV \\
\hline Constant & $15.39 * * *(2.38)$ & $14.57^{* * *}(2.82)$ \\
\hline \multicolumn{3}{|l|}{ Discretionary } \\
\hline $\begin{array}{l}\text { Dam height } \\
\mathrm{kW} / 10^{3} \\
\text { Electricity price } \\
\text { East } \\
\text { West } \\
\text { Rivermile } \\
\text { Endangered river }\end{array}$ & $\begin{array}{rr}0.01 * * * & (0.00) \\
0.01 * * & (0.00) \\
-0.47^{* * *} & (0.14) \\
-2.87 & (1.73) \\
-2.31 & (1.79) \\
0.00 \quad(0.00) \\
2.59 * * * & (0.76)\end{array}$ & $\begin{array}{rr}0.01 * * * & (0.00) \\
0.00 * * & (0.00) \\
-0.50^{* * *}(0.17) \\
-2.03 \quad(2.01) \\
-1.53 \quad(2.18) \\
0.00 \quad(0.00) \\
2.51^{* * *}(0.81)\end{array}$ \\
\hline \multicolumn{3}{|l|}{ Interest group } \\
\hline $\begin{array}{l}\text { Private owner } \\
\text { Multiple owner } \\
\text { Intervenors }\end{array}$ & $\begin{array}{r}1.69^{* * *}(0.52) \\
-0.06 \quad(0.05) \\
0.27^{* * *}(0.03)\end{array}$ & $\begin{array}{r}1.63^{* * *}(0.54) \\
-0.06 \quad(0.05) \\
0.29^{* * *}(0.10)\end{array}$ \\
\hline \multicolumn{3}{|l|}{ Congressional } \\
\hline $\begin{array}{l}\text { LCV score } \\
\text { Senate committee } \\
\text { ECPA }\end{array}$ & $\begin{array}{r}2.59^{* * *}(0.97) \\
-0.54 \quad(0.56) \\
2.90^{* * *}(0.51)\end{array}$ & $\begin{array}{r}2.68^{* * *}(0.98) \\
-0.52 \quad(0.56) \\
2.92 * * *(0.60)\end{array}$ \\
\hline \multicolumn{3}{|l|}{ History } \\
\hline $\begin{array}{l}\text { Relicense } \\
\text { History } \\
\text { ALP }\end{array}$ & $\begin{array}{r}-4.50^{* * *}(1.17) \\
-0.22^{* * *}(0.08) \\
2.84 * * *(0.90)\end{array}$ & $\begin{array}{r}-4.29 * * *(1.23) \\
-0.25^{* * *}(0.09) \\
2.95^{* * *}(0.92)\end{array}$ \\
\hline & $R^{2}=0.46$ & $R^{2}=0.46$ \\
\hline
\end{tabular}

Note: Figures in parentheses are standard errors.

* Significant at the $10 \%$ level; ${ }^{* *}$ significant at the $5 \%$ level; *** significant at the $1 \%$ level.

that they require greater environmental protection. Older dams, meanwhile, have presumably been negatively affecting riverbeds for longer, so a case could be made that they require greater environmental protection. On balance and in the aggregate, the effect a priori is expected to be insignificant.

History is a count variable indicating the average number of environmental licensing requirements issued by $\mathrm{FERC}$ in the year before a particular project applied for a new license. Figure 5 and Table 4 both indicate that, for the most part, the average number of environmental requirements issued by FERC, per license, has been increasing over time. But there is no particular reason to assume that the average number of requirements issued in the year directly before a license application should have any effect on the number of requirements subsequently issued in a wholly unrelated license. Aside from behavioral theories, there is no obvi-
TABLE 6

First-Stage OLS IV Regression

\begin{tabular}{|c|c|c|}
\hline Variable & Coefficient & Std. Error \\
\hline Constant & $-18.37^{* * *}$ & 4.78 \\
\hline \multicolumn{3}{|l|}{ Sociodemographic } \\
\hline $\begin{array}{l}\text { Population } / 10^{3} \\
\% \text { age } 0-24 \\
\% \text { age }>75 \\
\% \text { bach. degree } \\
\text { Median income } 110^{3} \\
\% \text { below poverty } \\
\text { Housing units } / 10^{3} \\
\text { Labor force } 10^{3} \\
\text { Unemployed } 110^{3} \\
\text { Total farms } \\
\text { Manf. Earnings } / 10^{3} \\
\text { Gov. revenue } 10^{3}\end{array}$ & $\begin{array}{l}-0.12^{* * *} \\
0.01 \\
0.12 \\
0.09 \\
0.16^{* *} \\
0.23^{*} \\
0.18^{* * *} \\
0.09^{* *} \\
0.45^{* *} \\
-0.00 \\
-0.00^{*} \\
0.00\end{array}$ & $\begin{array}{l}0.03 \\
0.05 \\
0.23 \\
0.09 \\
0.07 \\
0.13 \\
0.06 \\
0.04 \\
0.20 \\
0.00 \\
0.00 \\
0.00\end{array}$ \\
\hline \multicolumn{3}{|l|}{ Dam characteristics } \\
\hline $\begin{array}{l}\text { Dam height } \\
\mathrm{kW} / 10^{3} \\
\text { Electricity price } \\
\text { East } \\
\text { West } \\
\text { Rivermile } \\
\text { Endangered river } \\
\text { Private owner } \\
\text { Multiple owner } \\
\text { LCV score } \\
\text { Senate committee } \\
\text { ECPA } \\
\text { Relicense } \\
\text { History } \\
\text { ALP }\end{array}$ & $\begin{array}{l}0.03^{* * *} \\
0.01^{* * *} \\
0.81^{* * *} \\
6.48^{*} \\
10.03^{* * *} \\
0.00^{* *} \\
2.41^{*} \\
-0.65 \\
0.17^{* *} \\
0.11 \\
0.32 \\
1.63 \\
3.55^{*} \\
-0.02 \\
-0.95\end{array}$ & $\begin{array}{l}0.01 \\
0.00 \\
0.25 \\
3.36 \\
3.37 \\
0.00 \\
1.28 \\
0.87 \\
0.08 \\
1.62 \\
0.94 \\
0.99 \\
1.95 \\
0.17 \\
1.52\end{array}$ \\
\hline$A L P$ & & $R^{2}=0.34$ \\
\hline
\end{tabular}

* Significant at the $10 \%$ level; ** significant at the $5 \%$ level; *** significant at the $1 \%$ level.

ous reason why the coefficient on this variable should not be insignificant. If it turns out instead to have an effect, this would be an indication that FERC is subject to behavioral effects and that licensing decisions are unexpectedly (and perhaps unwarrantedly?) path dependent.

Finally, $A L P$ is a dummy variable indicating that a project applied for a new license through the ALP, as opposed to the TLP. The most recent licensing procedure possibility, the ILP, is not represented in our sample as no new licenses had as yet been fully processed under this procedure. The ALP was designed to encourage cooperation among all the stakeholders in a licensing process, which has tended to imply a rebalancing of the environmental/ 
TABLE 7

Determinants of the Number of ENVIRonmental ReQuirements PER License (WITH ENVIRonmental INTEREST GROUPS DISAGGREGATED)

\begin{tabular}{|c|c|c|c|}
\hline Variable & Model 2 & Model 3 & Model 4 \\
\hline Constant & $13.82^{* * *}(2.45)$ & $15.45^{* * *}(2.34)$ & $14.69 * * *(2.32)$ \\
\hline \multicolumn{4}{|l|}{ Discretionary } \\
\hline $\begin{array}{l}\text { Dam height } \\
k W / 10^{3} \\
\text { Electricity price } \\
\text { East } \\
\text { West } \\
\text { Rivermile } \\
\text { Endangered river }\end{array}$ & $\begin{array}{cc}0.02^{* * *} & (0.00) \\
0.00^{* *} & (0.00) \\
-0.32^{* * *} & (0.14) \\
-2.68 & (1.74) \\
-1.57 & (1.81) \\
0.00 & (0.00) \\
2.25^{* * *} & (0.77)\end{array}$ & $\begin{array}{cc}0.01^{* * *}(0.00) \\
0.00^{* *}(0.00) \\
-0.49^{* * *}(0.13) \\
-3.10^{*}(1.70) \\
-2.75 \quad(1.76) \\
0.00 \quad(0.00) \\
2.40^{* * *}(0.75)\end{array}$ & $\begin{array}{cc}0.01 * * * & (0.00) \\
0.00^{* *} & (0.00) \\
-0.44^{* * * *} & (0.13) \\
-2.71 & (1.69) \\
-2.53 & (1.75) \\
0.00 & (0.00) \\
2.08^{* * *} & (0.75)\end{array}$ \\
\hline \multicolumn{4}{|l|}{ Interest group } \\
\hline $\begin{array}{l}\text { Private owner } \\
\text { Multiple owner } \\
\text { Sportsfishing } \\
\text { Boating } \\
\text { Historical } \\
\text { Endangered species } \\
\text { Water quality } \\
\text { Recreation } \\
\text { Federal } \\
\text { State } \\
\text { Local } \\
\text { Public } \\
\text { Private } \\
\text { NGO }\end{array}$ & $\begin{array}{lc}1.69^{* * *} & (0.53) \\
-0.06 & (0.05) \\
-0.09 & (0.26) \\
-0.17 & (0.25) \\
0.00 & (0.25) \\
0.19 & (0.32) \\
0.51^{* *} & (0.20) \\
0.01 & (0.20)\end{array}$ & $\begin{array}{l}0.33^{* * *}(0.09) \\
0.39^{* * *}(0.10) \\
0.02^{* * *}(0.01)\end{array}$ & $\begin{array}{c}0.46^{* * * *}(0.06) \\
-0.01 \quad(0.15) \\
0.03^{* * *}(0.01)\end{array}$ \\
\hline \multicolumn{4}{|l|}{ Congressional } \\
\hline $\begin{array}{l}\text { LCV score } \\
\text { Senate committee } \\
\text { ECPA }\end{array}$ & $\begin{array}{cc}2.22^{* *}(0.99) \\
-0.40 \quad(0.56) \\
2.86^{* * *}(0.52)\end{array}$ & $\begin{array}{cc}2.29^{* *} & (0.96) \\
-0.83 & (0.55) \\
2.76^{* * * *}(0.50)\end{array}$ & $\begin{array}{cc}2.04^{* *} & (0.96) \\
-0.85 & (0.55) \\
2.75^{* * *} & (0.50)\end{array}$ \\
\hline \multicolumn{4}{|l|}{ History } \\
\hline $\begin{array}{l}\text { Relicense } \\
\text { History } \\
\text { ALP }\end{array}$ & $\begin{array}{r}-4.65^{* * *}(1.18) \\
-0.19^{* *}(0.08) \\
2.41^{* * *}(0.91)\end{array}$ & $\begin{array}{r}-4.42^{* * *}(1.15) \\
-0.18^{* *}(0.08) \\
2.51^{* * *}(0.88)\end{array}$ & $\begin{array}{r}-4.80^{* * *}(1.16) \\
-0.14^{*} \quad(0.08) \\
2.55^{* * *}(0.88)\end{array}$ \\
\hline & $R^{2}=0.47$ & $R^{2}=0.48$ & $R^{2}=0.49$ \\
\hline
\end{tabular}

Note: Figures in parentheses are standard errors.

* Significant at the $10 \%$ level; ${ }^{* *}$ significant at the $5 \%$ level; ${ }^{* * *}$ significant at the $1 \%$ level.

hydropower trade-off toward more environmental concern. We would therefore expect the coefficient on this variable to be positively significant.

\section{EMPIRICAL APPROACH AND INITIAL RESULTS}

We analyze FERC's power/environmental trade-off decision through regression analysis, with the number of environmental requirements as the dependent variable $(R)$ and a set of variables corresponding to the categories of influence in our theoretical model (discretion $D$, interest groups $I$, Congress $C$, and history $H$ ) as the independent variables. ${ }^{24}$ Each observation $j$ represents a hydroelectric dam license:

$$
R_{j}=f\left(D_{j}, I_{j}, C_{j}, H_{j}\right)+\varepsilon_{j} .
$$

Model 1 in Table 5 presents the initial

\footnotetext{
${ }^{24}$ Ordinary least squares (OLS) and Poisson specifications were both run, and as there were no changes in the size or significance of any of the key regressors, for ease of interpretation we present the OLS results in the following tables.
} 
results. We find evidence in support of all four of the categories of influence described in the framework setup. We find, for example, that Dam height and $k W$ are both positively significant, implying that the larger the dam, the greater the regulatory stringency imposed on a license. Similarly, the more unhealthy the river, the greater the environmental regulatory burden that FERC mandates. In a nod to the consumer, however, as electricity prices increase, FERC reduces the regulatory burden slightly. While geography, in the form of transmission grid utilized, is insignificant in FERC decision making, the significance of the other variables in the discretionary category implies that FERC is able and willing to exhibit a measure of authority in issuing its regulatory decisions.

The interest group variables are also significant, though not necessarily in the direction expected. The coefficient on Private owner is large and positive, implying that private utility dam owners receive, on average, an $11 \%(1.69 / 15.39)$ greater regulatory burden than other types of dam owners. We had hypothesized a priori that private utility dam owners would have deeper pockets, greater experience, and a more substantial interest in lobbying the regulator to decrease the regulatory burden, but we found instead that FERC tended to increase the regulatory burden of private utility dam owners relative to all other ownership types. This may be because private utility owners generally own projects that require substantial environmental attention, ${ }^{25}$ or because FERC is battling its reputation as being biased toward such owners due to their initial mandate to encourage hydroelectric production. The environmental interest groups, Intervenors, are also found to have a significantly positive effect on the regulatory burden. The coefficient is small, however (although its standard deviation is large), so we explore this variable in greater detail in later regressions (Table 7).

\footnotetext{
cant.
}

It is the congressional variables and the history variables that have high significance and the largest coefficients in the table, implying that, overall, while all categories of influence matter, Congress and history matter the most to FERC decision making. The positively significant coefficient on $L C V$ score implies that liberal-leaning senators from a project's state have the power to increase the regulatory burden by $17 \%$ on average. This is a substantial effect. Even greater is the effect of passage of the ECPA legislation. Projects that were licensed after this legislation went into effect received a regulatory burden that was $19 \%$ higher on average. These results lend strong support to the congressional dominance theory of regulatory agency decision making.

Relicense turns out to be the regressor with the largest coefficient, by far. Its negative significance implies that older projects receive a less stringent regulatory burden than brand new hydroelectric facilities. Exactly why this would be, is unclear. Newer projects could be located on more pristine land, implying that in order to protect them FERC grants their license only with high environmental barriers to pass. A detailed look at each of these observations, however, fails to imply this. An alternative explanation is that FERC is exhibiting a form of de facto grandfathering on older licenses, even though such behavior is not a part of their mandate and is, indeed, forbidden by judicial decree.

History, too, is negatively significant, though its coefficient is small. This implies that the stringency of FERC's regulatory decisions are path dependent; higher average regulatory burdens from the year before lead FERC to cool off slightly the following year, on wholly unrelated licenses (this effect can also be seen in Figure 5). This is an entirely surprising result. It implies, in essence, that a dam relicensed in, say, California in 1993 affected the relicensing procedure of a wholly unrelated dam in Maine in 1994. Historical biases have been studied extensively in the psychology and economics literatures at the individual decision-making level, but extending such 
effects to federal regulatory decision making is still quite novel.

Finally, $A L P$ is significant in the positive direction, implying that FERC is acting within the institutional constraints of its system. ALP is a form of regulatory procedure (the alternative in this time period being the TLP) designed to increase early consideration of environmental issues and goals in the licensing process. When it is used, it indeed tends to correlate with greater environmental stringency on a license, by $18 \%$ on average.

\section{Endogeneity}

A central concern in the estimation strategy is the potential simultaneity of environmental interest group involvement and environmental requirements issued. It is conceivable that levels of intervenor involvement reflect knowledge of impending environmental requirements, rather than acting solely as a stimulus for them. If this is the case, intervenors who actually have zero influence on the outcome of the licensing process could appear instead to have a statistically significant positive effect. Any significant coefficients reported for such an intervenor in a non-endogeneity-corrected model would then be spurious.

The existence of factors causing this type of bias would be quite a policy revelation, implying enormous wasted efforts by intervenors, who regularly spend thousands of dollars mobilizing individuals to comment and protest directly to FERC. It would also imply enormous wasted social costs by the regulatory staff, who must by law spend time and effort processing intervenor commentary. Intuitively, such a conclusion seems implausible, especially when one considers the numerous legislative and judicial rulings designed to explicitly emphasize and encourage intervenor effects on the relicensing process. ${ }^{26}$ Official interve-

\footnotetext{
${ }^{26}$ The Administrative Procedures Act of 1946 established the legal mandate for public participation in regulatory decision making. The courts also solidified the role of interest groups, in the relicensing process in particular, as early as 1967 in Udall v. Federal Power Commission ( 387 US 428).
}

nors in the relicensing process carry the very real power to appeal any relicense issued by FERC to the U.S. Court of Appeals, with the potential for the entire relicense to be overturned and renegotiated. With such power, it would be foolhardy for FERC not to incorporate intervenor commentary into their objective function, in order to avoid the costly and politically damning fate of the U.S. appeals process.

Nevertheless, strongly intuitive judgment calls have been proven false by thorough research before. For this reason, a truly complete exposition of the model should include some econometric attention to potential simultaneity bias. We have chosen to address this concern by instrumenting for intervenor involvement with a set of exogenous sociodemographic and dam characteristic variables. ${ }^{27}$ The rationale for these instruments stems from environmental economic theory. Kolstad and others (Braden and Kolstad 1991) have shown that many environmental goods such as clean air and clean water are normal goods, demand for which generally increases as income increases. Studies have additionally shown that more educated, younger populations demand greater environmental amenities than less educated, poor, aging populations. As well, populations with a high unemployment rate or a large percentage of the workforce employed in manufacturing will desire fewer environmental amenities if they come at the expense of working conditions or employment prospects. Therefore, there is a sound theoretical basis for using instruments for intervenor involvement such as median income, unemployment rate, manufacturing output, and education level.

We additionally include the dam characteristic variables as instruments, under the assumption that intervenors, after their initial proclivity to act is determined by sociodemographic factors, ultimately get

\footnotetext{
${ }^{27}$ The complete list of instruments used in our initial specification can be found in Table 1 . The results of the instrumental variables regression can be found in Table 6 .
} 
involved in a relicensing proposal due to the specific characteristics of a project.

The results for our first specification appear almost identical whether corrected for potential endogeneity bias or not (Model 1 vs. Model IV, Table 5). In order to test exogeneity explicitly, we conduct a Durbin-Wu-Hausman test and find that the endogeneity of intervenor participation is not significant (Prob $>F=0.7082$ ). For this reason, as well as for the practical consideration of the near impossibility of finding unique instruments for all of the further specifications presented, we do not attempt to correct for potential endogeneity bias in the rest of the specifications presented. $^{28}$

\section{THE SPECIAL ROLE OF INTEREST GROUPS}

Interest group effects are increasingly of interest in the literature (Kosnik 2010; Mitchener 2007; Knittel 2006; Li et al. 2005; Aidt 2002; Oates and Portney 2001). For this reason, in Table 7, we explore the effect of Intervenors in greater detail, disaggregating this variable first by its advocacy type, then by its membership base, and finally by its market type. We find that not much of significance can be detected when the intervenors are broken down by advocacy type. This implies that the influence interest groups garner from FERC does not appear to be related to what they are arguing for, instead, what appears to matter more in gaining influence over

\footnotetext{
${ }^{28}$ Further support for the decision not to be overly concerned with potential endogeneity of intervenor comments comes from recent research that bolsters such an assumption: In a study of intervenor group comments received by the EPA during consideration of additions to the U.S. endangered species list, Ando (2001) specifically asks the question whether interest group comments are submitted endogenously, whereby the pressure from one interest group increases or decreases with the pressure intensity coming from an opposing group, or whether interest group comments are instead motivated by benefit/cost considerations that can accrue to the groups as a result of the final regulatory decision. Her results confirm that interest groups do not appear to act endogenously but instead respond to internal benefit/cost calculations.
}

FERC decision making is the geographic range of the interest groups, and an interest group's market type. Federal and statebased interest groups, for example, have large influences as measured by coefficient size, implying that broad-based groups have more clout than smaller, local interest groups. The significance of Public and $N G O$ market types imply that interest group structure matters too, with intragovernment lobbying showing by far the biggest effect on FERC decision making. This is not surprising to those within government, at organizations such as the Fish and Wildlife Service and the National Marine Fisheries Service, who note that they often have a statutorial obligation to involve themselves in hydropower relicensing proceedings. These intriguing results call for more research in the future, as they hint at a degree of complexity behind interest group influence on the regulatory process that has not been fully explored in the literature to date.

\section{CONCLUSION}

The environmental protection/energy production trade-off that FERC is making every time it issues a new hydroelectric license has complex roots. This paper sought to uncover some of those roots and found that many categories of influence exist on the trade-off decision, including regulatory discretion, regulatory capture, congressional dominance, and historical and institutional factors. Of these, the greatest influences appear to come from Congress and history. Additional research into these factors would be worthwhile. For example, we know that direct legislation on FERC's mandate, such as the ECPA, made a difference in shifting the trade-off toward environmental protection, but does indirect legislation have similar effects? How about amendments thrown into broader bills, like the 2005 Energy Bill? Also, incorporating history and behavioral theories, such as starting point bias, in regulatory models is still a novel undertaking. There needs to be more research into decision making at other 
regulatory institutions, such as the FDA or the EPA, to see if these types of behavioral variables are effectual there as well.

Now that we have a better idea how to affect FERC decision making, future research should also investigate the level of energy production versus environmental protection we seek to achieve. If it turns out that we are currently not balancing these twin goals efficiently, then the results from this research indicate that we should pass new legislation or implement reform at FERC in an attempt to get there. Actions like these can help us achieve the difficult balance of efficient levels of energy production and environmental protection.

\section{References}

Aidt, Toke S. 2002. "Strategic Political Participation and Redistribution." Economics and Politics 14 (1): 19-40.

Alley, William M., Thomas E. Reilly, and O. Lehn Franke. 1999. Sustainability of Ground-Water Resources. U.S. Geological Survey, Circular 1186. Denver, CO: U.S. Geological Survey.

Anderson, Keith B. 1993. "Agency Discretion or Statutory Direction: Decision Making at the U.S. International Trade Commission." Journal of Law and Economics 36 (2): 915-35.

Anderson, Mark T., and Lloyd H. Woosley, Jr. 2005. Water Availability for the Western United States-Key Scientific Challenges. Circular 1261. Reston, VA: U.S. Geological Survey.

Ando, Amy Whritenour. 1999. "Waiting to Be Protected under the Endangered Species Act: The Political Economy of Regulatory Delay." Journal of Law and Economics 42 (1): 29-60. 2001. "Economies of Scope in Endangered-Species Protection: Evidence from Interest-Group Behavior." Journal of Environmental Economics and Management 41 (93): 312-32.

Bartel, Ann P., and Lacy Glenn Thomas. 1987. "Predation through Regulation: The Wage and Profit Effects of the Occupational Safety and Health Administration and the Environmental Protection Agency." Journal of Law and Economics 30 (2): 239-64.

Beard, T. Randolph, David L. Kaserman, and John W. Mayo. 2003. "A Graphical Exposition of the Economic Theory of Regulation." Economic Inquiry 41 (4): 592-606.

Becker, Gary S. 1983. "The Theory of Competition among Pressure Groups for Political Influ- ence." Quarterly Journal of Economics 98 (3): 371-400.

Braden, John B., and Charles D. Kolstad. 1991. Measuring the Demand for Environmental Quality. New York: Elsevier Science.

Carpenter, Daniel P. 2002. "Groups, the Media, Agency Waiting Costs, and FDA Drug Approval." American Journal of Political Science 46 (3): 490-505.

Crone, Lisa, and John Tschirhart. 1998. "Separating Economic from Political Influences on Government Decisions." Journal of Economic Behavior and Organization 35 (4): 405-25.

Cropper, Maureen L., William N. Evans, Stephen J. Berardi, Maria M. Ducla-Soares, and Paul R. Portney. 1992. "The Determinants of Pesticide Regulation: A Statistical Analysis of EPA Decision Making." Journal of Political Economy 100 (1): 175-97.

Dranove, David, and David Meltzer. 1994. "Do Important Drugs Reach the Market Sooner?" RAND Journal of Economics 25 (3): 402-23.

Edwards, Brian K. 2003. The Economics of Hydroelectric Power. Northampton, MA: Edward Elgar Publishing.

Edwards, Brian K., Silvio J. Flaim, and Richard E. Howitt. 1999. "Optimal Provision of Hydroelectric Power under Environmental and Regulatory Constraints," Land Economics 75 (2): 267-83.

Federal Energy Regulatory Commission, Office of Hydropower Licensing (FERC). 1991. Evaluating Relicense Proposals at the Federal Energy Regulatory Commission. Washington, DC: FERC.

2004. Handbook for Hydroelectric Project Licensing and $5 \mathrm{MW}$ Exemptions from Licensing . Washington, DC: FERC.

Gilligan, Thomas W., William J. Marshall, and Barry R. Weingast. 1989. "Regulation and the Theory of Legislative Choice: The Interstate Commerce Act of 1887." Journal of Law and Economics 32 (1): 35-61.

Helland, Eric. 1999. "The Waiver Pork Barrel: Committee Membership and the Approval Time of Medicaid Waivers." Contemporary Economic Policy 17 (3): 401-11.

Kahneman, Daniel, and Tversky Amos. 1979. "Prospect Theory: An Analysis of Decision under Risk." Econometrica 47 (2): 263-91.

Knittel, Christopher R. 2006. "The Adoption of State Electricity Regulation: The Role of Interest Groups.' Journal of Industrial Economics 54 (2): 201-22.

Kosnik, Lea-Rachel. 2006. "Sources of Bureaucratic Delay: A Case Study of FERC Dam 
Relicensing." The Journal of Law, Economics, and Organization 22 (1): 258-88.

2010. "Time to Pick a Fight? Interest Group Decision Making to Enter the Hydropower Regulatory Process." Eastern Economic Journal 36 (1): 11-32.

Kotchen, Matthew J., Michael R. Moore, Frank Lupi, and Edward S. Rutherford. 2006. "Environmental Constraints on Hydropower: An Ex-Post Benefit-Cost Analysis of Dam Relicensing in Michigan." Land Economics 82 (3): 384403.

Li, Wei, Christine Qiang, and Lixin Xu. 2005. "Regulatory Reforms in the Telecommunications Sector in Developing Countries: The Role of Democracy and Private Interests." World Development 33 (8): 1307-24.

Magat, Wesley A., Alan J. Krupnick, and Winston Harrington. 1986. Rules in the Making: A Statistical Analysis of Regulatory Agency Behavior. Washington, DC: Resources for the Future.

McCubbins, Matthew D., Roger G. Noll, and Barry R. Weingast. 1987. "Administrative Procedures as Instruments of Political Control." Journal of Law, Economics, and Organization 3 (2): 243-77.

Mitchener, Kris James. 2007. "Are Prudential Supervision and Regulation Pillars of Financial Stability? Evidence from the Great Depression." Journal of Law and Economics 50 (2): 273-302.

North, Douglass C. 1990. Institutions, Institutional Change, and Economic Performance. New York: Cambridge University Press.

Nowell, Clifford, and John Tschirhart. 1990. "The Public Utility Regulatory Policy Act and Regulatory Behavior." Journal of Regulatory Economics 2 (1): 21-36.

. 1993. "Testing Theories of Regulatory Behavior." Review of Industrial Organization 8 (6): 653-668.

Oates, Wallace E., and Paul R. Portney, 2001. "The Political Economy of Environmental Policy." RFF Discussion Paper 01-55. Washington, DC: Resources for the Future.

Olson, Mary K. 1995. "Regulatory Agency Discretion among Competing Industries: Inside the FDA." Journal of Law, Economics, and Organization 11 (2): 378-405.
1997. "Firm Characteristics and the Speed of FDA Approval." Journal of Economics and Management Strategy 6 (2): 377-401.

2000. "Regulatory Reform and Bureaucratic Responsiveness to Firms: The Impact of User Fees in the FDA." Journal of Economics and Management Strategy 9 (3): 363-95.

Peltzman, Sam. 1976. "Toward a More General Theory of Regulation." Journal of Law and Economics 19 (2): 211-40.

Sabatier, Paul A., John Loomis, and Catherine McCarthy. 1995. "Hierarchical Controls, Professional Norms, Local Constituencies, and Budget Maximization: An Analysis of U.S. Forest Service Planning Decisions." American Journal of Political Science 39 (1): $204-42$.

Sigman, H. 2001. "The Pace of Progress at Superfund Sites: Policy Goals and Interest Group Influence." Journal of Law Economics 44 (1): 315-44.

Spence, David B. 1997. "Agency Policy Making and Political Control: Modeling Away the Delegation Problem." Journal of Public Administration Research and Theory 7 (2): 199-219.

Stigler, George J. 1971. "The Theory of Economic Regulation." Bell Journal of Economics and Management Science 2 (1): 3-21.

U.S. Department of Energy (U.S. DOE). 2006. "Feasibility Assessment of the Water Energy Resources of the United States for New Low Power and Small Hydro Classes of Hydroelectric Plants." DOE-ID-11263. Idaho Falls, ID: Idaho National Laboratory, U.S. DOE.

Veltrop, Jan. 1997. "Sustainable Hydropower at Home and Abroad." In Waterpower '97: Proceedings of the International Conference on Hydropower, ed. Daniel J. Mahoney, 1257-66. Reston, VA: American Society of Civil Engineers. Weingast, Barry R., and Mark J. Moran. 1983. "Bureaucratic Discretion or Congressional Control? Regulatory Policymaking by the Federal Trade Commission." Journal of Political Economy 91 (5): 765-800.

Wood, B. Dan. 1988. "Principles, Bureaucrats, and Responsiveness in Clean Air Enforcements." American Political Science Review 82 (1): 213-34.

Yaffee, Steven Lewis. 1982. Prohibitive Policy: Implementing the Federal Endangered Species Act. Cambridge, MA: MIT Press. 
Copyright of Land Economics is the property of University of Wisconsin Press and its content may not be copied or emailed to multiple sites or posted to a listserv without the copyright holder's express written permission. However, users may print, download, or email articles for individual use. 